\title{
FOREIGN DIRECT INVESTMENT AND ECONOMIC GROWTH
NEXUS: EMPIRICAL INSIGHT FROM GUINEA
}

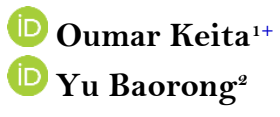

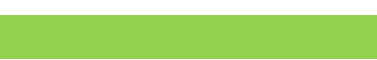

Article History

Received: 12 October 2020 Revised: 17 December 2021 Accepted: 6 January 2022 Published: 19 January 2022

\section{Keywords \\ FDI}

Bounds test

Credit to private sector

GDP growth

Inflation

Trade openness.

JEL Classification: E22; F 14; O11; O16; P44; P45.

\author{
${ }^{1,2}$ School of Insurance and Economics, University of International Business \\ and Economics, Beijing, China. \\ 'Email:oumar.keita2016@yahoo.com Tel: +8618514477352 \\ ${ }^{2}$ Email: bryu@uibe.edu.cn Tel: +8613581573676
}

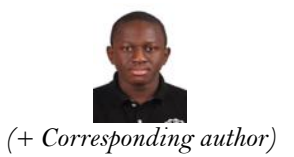

ABSTRACT

Although the predominant theoretical literature presumed foreign capital inflows to carry broad benefits to recipient nations, this assumption has been recently questioned in Guinea since the resulting GDP growth has weakly impacted social welfare. This empirical study offers a better insight of the extent to which foreign direct investment (FDI) influences economic growth in the Guinean context over the period 1990-2017. The per GDP FDI net inflows and GDP growth rate are respectively employed as FDI estimate and economic advancement indicator. The findings established in this study included: first, foreign direct investment in the long run positively affects economic advancement in Guinea at $1 \%$ significance level. This outcome suggests that $1 \%$ raise in FDI per GDP leads to 0.45 increase in GDP growth. Moreover, this finding is in line with the main literature related to foreign investment induced effects in Africa and other developing regions. Second, the short run coefficients suggest the same story exposed by the long run investigation. FDI per GDP [L1], [L2] positively and significantly influences economic growth in the Guinean context. Even though there is strong evidence that FDI positively affects growth in Guinea, government should consider the form of foreign investments to be promoted in the country. The study recommends that resource seeking type without transformation must be discouraged for the benefit of market or efficiency seeking investment. By doing so, Guinean economy will experience healthier and welfare enhancing growth.

Contribution/ Originality: This paper is one of very few studies that investigated short and long run impact of foreign direct investment on economic growth of Guinea, thereby providing empirical evidence showing how FDI stimulates GDP growth within the Guinean context.

\section{INTRODUCTION}

Recently, the nexus between foreign investment (FDI) and economic advancement has been one of the controversial subjects which has resuscitated debates among scholars and governments in developing countries. In Solow growth framework, for instance, FDI allowed recipient nations to achieve a certain level of investment that surpassed their local saving capacity. The exogenous growth theory also asserts that FDI's effect on GDP growth is assumed to be close to a short run. Given the diminishing marginal returns to physical capital, the recipient economy in the long run could converge to the steady growth rate as if FDI had never taken place. On the other hand, Romer endogenous growth theory underlines the role of innovation and human capital. It posits that FDI can undoubtedly affect economic growth as it engenders increasing returns in productivity through spillovers and positive externalities. 
Moreover, FDI-implied merits and singularly in the types of inducement offered to foreign corporations have been recently questioned. This debate is fueled by the ambiguous empirical findings related to FDI, engendering spillovers for recipient economies, both at the macro and micro levels. A recent survey conducted by Sabina and Eldin (2015) displayed that valuable spillovers generated by FDI for host economies were weak. Olawumi and Olufemi (2016) when reviewing micro data about spillovers from foreign corporations conclude that impacts were predominantly negative. However, Liming (2014) found no consistent linkage among GDP growth and the size of inward foreign direct investment fluctuated. He further supported the need to take into consideration different factors and circumstances that stimulated or inhibited spillovers. These mixed views might have resulted from erroneous places such as data constraints, or when macro empirical analysis that assessed the impact of inward investment flow on recipient nations did not take into account the sector features in which FDI was oriented.

Even though it may appear usual to advocate that foreign capital carries valuable benefits to recipient economies, such benefits can diverge from one country to another or across sectors. Paula (2014) stated that the sphere for nexus between overseas subsidiaries and domestic suppliers is usually restrained to the primary sector. Several wide and inclusive linkages are observed in manufacturing sector while the scope for subcontracting and other types of partnership seems restrained for the services sector.

The current study aimed to investigate empirically the extent to which FDI promoted economic advancement in the Guinean context. The commonly cited merits such as human capital advancement, transfer of technology and know-how tended to be connected to secondary sector rather than extractive industries (mining). Within this study, we first analyzed the causality direction, followed by a the long and short run interaction among foreign investment and economic advancement in Guinea. This investigation is more relevant for Guinea since the large proportion of FDI is concentrated in mining sector. Hence, political elites, scholars and civil society might question the real impact of this resource seeking type of investment on GDP growth in Guinea.

This study would dually contribute to the domain. Primary, this empirical analysis would extend the knowledge about the nexus between foreign investment and economic advancement in the Guinean context. Second, to our awareness the influence of FDI on GDP was not previously examined econometrically in Guinea. Therefore, this study would stand as an original assessment that generated quantitative evidence of foreign capital and its associated impact on Guinean economy (despite the fact that our investigation is considering 1990-2017 period). The rest of this paper is set as follows: section 2 reviews the literature, section 3 portrays data and the variables, section 4 comments on the empirical results while conclusions are displayed in section 5.

\section{LITERATURE REVIEW ON FDI AND ECONOMIC GROWTH NEXUS}

Within this section are presented some theoretical arguments and empirical literature related to FDI induced effects on economic development.

\section{a. Theoretical Arguments on the Linkage between FDI and Growth}

Foreign investment is presumed to be a catalyst for economic advancement in developing countries (Xiaoying \& Xiaming, 2005). According to Liming (2014) multinational firms may become an important provenance of capital and technology since other sources are more volatile or scarce. FDI's role in expanding new technologies and transferring know how has been endorsed in several endogenous growth theories (Mohammad, Mahmoud, \& Liu, 2014). Enjoying these FDI related benefits persuade recipient governments to liberalize their trade regime and offer incentives to foreign investors. Such decisions comprise the removal of export restrictions for foreign corporations producing local and mutual agreement over legal challenges and commercial disputes. These reactions from developing economies have induced significant policy shifts from import substitution view to market friendly policies. 
Though the nexus among foreign direct investment and economic advancement seem to be vague, it is nevertheless perceived to have significant impact on recipient country via spillover effect (Zuzana, 2014). FDI may stimulate GDP via the rise of total factor productivity and the efficient utilization of resources within the host nation. This objective might be achievable through the following mechanisms: linkages among FDI and foreign trade flows, FDI induced externalities and spillovers on the local economic structure. Based on these viewpoints, countries like China, India, Malaysia, Singapore, Brazil have recorded substantial growth rate relying on FDI (Carlos \& Eddie, 2015).

Through the deployment of advanced technologies, introduction of new management practices and the training of human capital, foreign direct investment may also increase productivity in the recipient country (Paula, 2014). Multinational firms serving as catalyst can enable domestic enterprises to leapfrog their development stages. This process may speed up the structural adjustments and allow emerging economies to catch-up with the developed countries (Carlos \& Eddie, 2015). However, FDI having significant impact on least developed nations growth level is imputed to the existence of minimum externalities. Such countries are required to attain a certain development level in infrastructure, education, healthcare, governance and financial industry in order to fully enjoy FDI related benefits.

\section{b. Empirical Review on the Linkage between FDI and Economic Growth}

Several empirical studies have investigated the direct and indirect interaction between FDI and economic advancement using various econometric approaches. Nicholas (2021) analyzed the causal relationship between inward foreign investment and economic growth in Kenya, using the ARDL-bound testing approach. The results display that the current burgeoning FDI inflows that Kenya attracted in recent years are largely driven by the strong economic growth and prudent macroeconomic policies.

Oscar and Edson (2016) examined the linkage among Foreign direct investment and economic growth in Botswana, employing yearly time series data for the period 1980-2012. After performing a dynamic causality test and the Johansen co-integration framework, the findings showed that FDI had a long term relationship with GDP growth within Botswana context. However, they were not able to confirm whether it was FDI spurring economic growth or the opposite.

Gaurav (2015) investigated the relationship between foreign direct investment and economic growth in five BRICS countries over the period 1989-2012. After applying the panel cointegration approach and the causality analysis, results displayed that FDI and GDP growth have long run equilibrium linkage. It is thus important that policymakers remove obstacles to FDI and improve absorptive capacity in order to reap maximum growth effects.

Masipa (2014) estimated the impact of foreign direct investment on economic growth and employment in South Africa over 24 years. After conducting Johansen cointegration technique and the Granger causality test, the study found a positive long run relationship among FDI, GDP and employment in South Africa. The study concluded that foreign investment should be considered as an instrument to boost long term economic growth in the South African context.

Olawumi and Olufemi (2016) examined the influence of foreign direct investment inflows on economic growth in some selected African economies over 1980-2013 period. They used modified growth model, ordinary least squares and generalized method of moments framework. FDI inflows in Central African Republic were found not to have any statistically significant influence on economic growth. The panel analysis showed that FDI impact on GDP growth in African countries was limited or negligible.

Sajid and Lan (2010) analyzed the link between foreign direct investment and economic growth in 61 Vietnam provinces from 1996-2005. The simultaneous equations model revealed a two-way linkage among FDI inflows and GDP growth in Vietnam. However, this outcome was not the case for each of the regions. Irfan, Mahmood, and Farid (2014) investigated a dynamic interaction among foreign investment inflows, domestic investment and 
economic growth in Pakistan over the period 1976-2010. After performing Johansen cointegration approach and Toda Yamamoto causality technique, the existence of long run interaction between the three variables was revealed. A bi-directional causality was further supported by Toda Yamamoto test.

Abdillahi and Mohd (2021) explored the impact of foreign direct investment inflows on Ethiopia's economic growth using 36 years' time series data. The vector auto regression (VAR) model found FDI to have a positive and significant effect on GDP advancement. Authors recommended policymakers to open up and restructure the financial and agriculture sectors so that Ethiopia can experience healthier growth.

Comprehensively, most prior research studies testing the causal linkage among foreign direct investment and GDP advancement are somewhat ambiguous. Empirical papers also employed different econometric approaches with assorted findings. However, as far as Guinea is concerned, no empirical assessment has been explicitly carried out till date.

\section{METHODOLOGY}

\subsection{Data and Variables Description}

To capture the causality direction and the associated linkage among inward FDI and economic advancement in Guinea, this empirical analysis adopted FDI per GDP net inflows and GDP growth rate as key indicators. Data of annual time series covered twenty-eight years (1990-2017) and variables were collected from World Bank glossary of statistics.

\subsection{Foreign Direct Investment Variable}

Foreign direct investment incorporates all kind of inward capital that enables nonresidents to acquire ownership in Guinean economy. Within this study, we employed FDI per GDP measure which was net inward FDI divided by GDP.

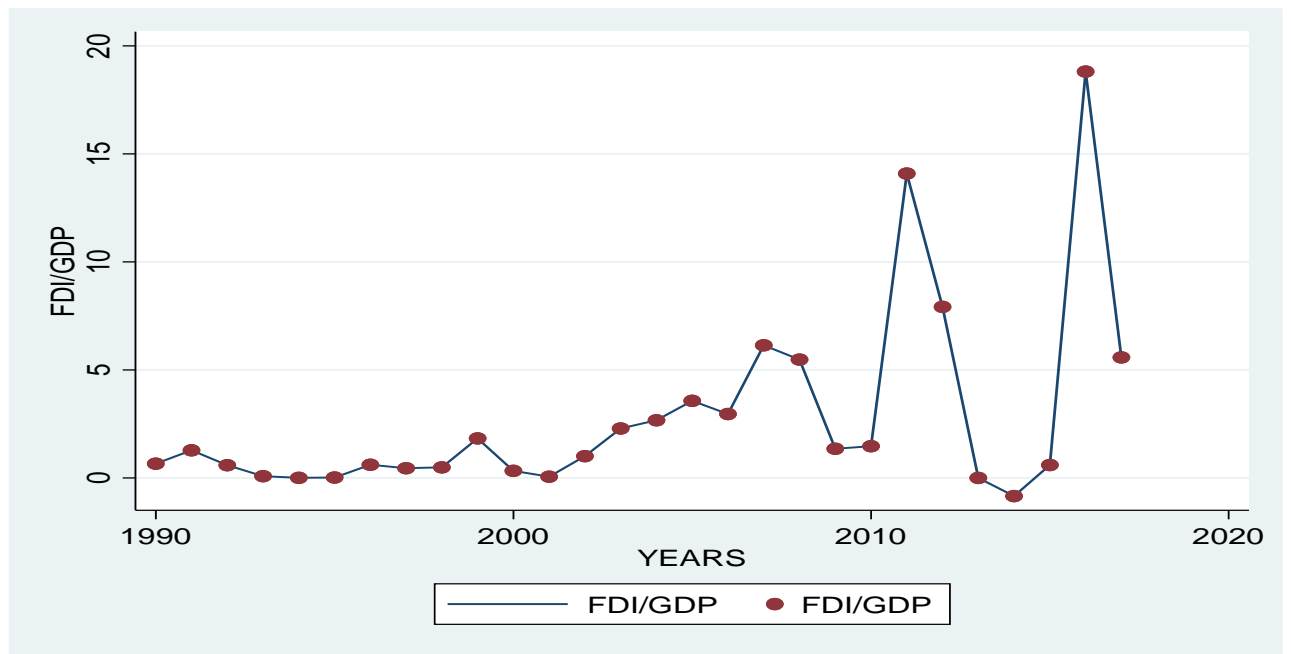

Figure 1. Foreign direct investment per GDP net inflows (1990-2017).

Figure 1 shows the progression of Foreign direct investment per GDP net inflows over the study period (19902017). It is obvious that FDI experienced noticeable fluctuations within the Guinean context, raising our curiosity on its related impact on Guinean economy.

\subsection{Economic Growth Variable}

Real GDP growth rate represents economic growth variable. It is commonly adopted to assess the dynamism of the country. In other terms, real GDP rise is considered as a sign of vitality and good health of the economy. 
Foreign investors also perceive it as a huge opportunity and often refer to when choosing their investment destination.

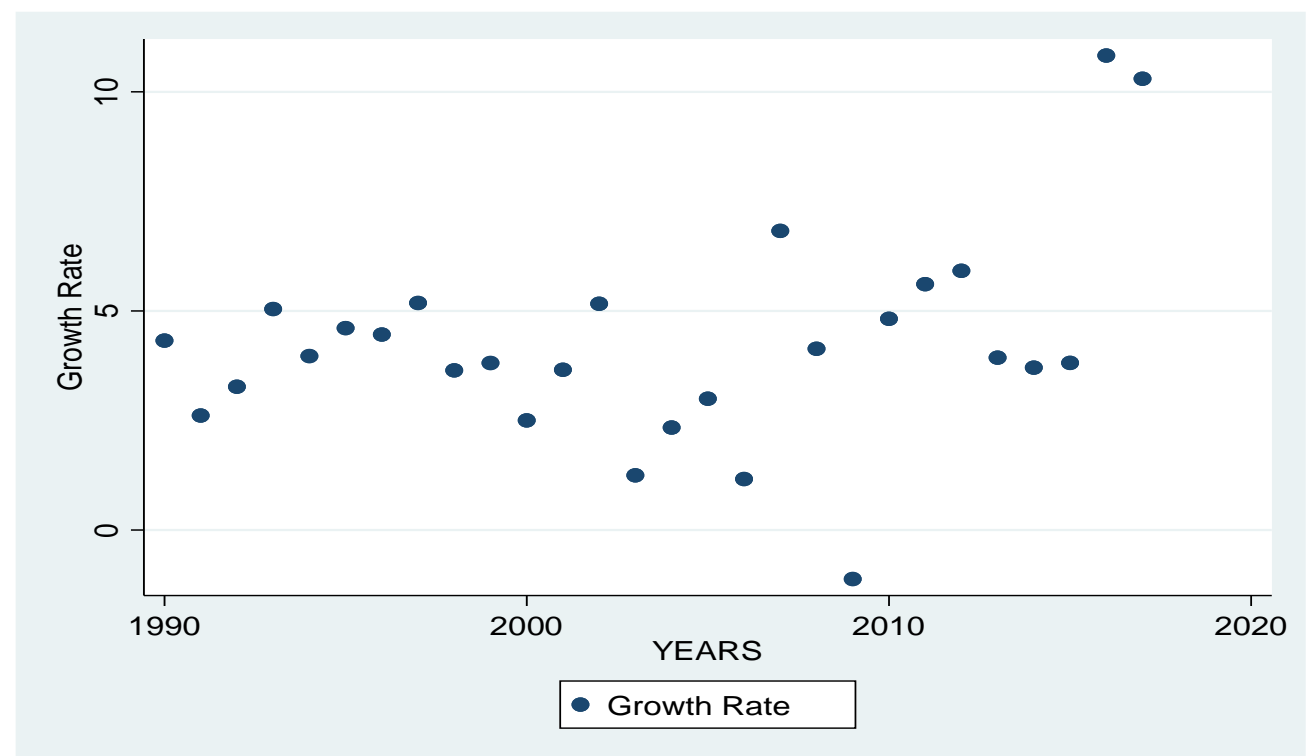

Figure 2. GDP growth rate (1990-2017).

Figure 2 shows the evolution of GDP growth rate over the study period (1990-2017). It is noticeable that Guinean growth rate experienced unsteadiness over decades due to political instability and other external shocks.

\subsection{Control Variables}

- Trade Openness reveals the extent to which a country is open to global trade and foreign capital. Openness is computed as the summation of exports and imports in percentage of GDP. Foreign investors scrutinize it when evaluating the attractiveness of the recipient nation.

- Inflation variable reflects price stability and the volatility of purchasing power within the host economy. It is assumed to be an appropriate proxy for macroeconomic steadiness.

- Domestic credit to private sector is expected to be a suitable indicator for financial advancement particularly for Guinea where stock markets are nonexistent. It basically comprises financial services such loans, equity and other facilities delivered by commercial banks.

\subsection{Models Estimation}

\subsubsection{Causality Direction between FDI and Economic Growth}

The study used the Granger framework which seemed to be an appropriate technique to test the causality direction among time series variables. For this purpose, the stationarity of the series was first checked before performing the co-integration test. The study adopted Augmented Dickey Fuller approach presented as follow:

$$
\Delta \mathrm{Y}_{\mathrm{t}}=\alpha+\beta_{\mathrm{t}}+\gamma \mathrm{Y}_{\mathrm{t}-1}+\delta_{1} \Delta \mathrm{Y}_{\mathrm{t}-1}+-----+\delta_{\mathrm{p}-1} \Delta \mathrm{Y}_{\mathrm{t}-\mathrm{p}+1}+\varepsilon_{\mathrm{t}}
$$

Where, $\alpha$ stands as a constant while $\beta$ represents the coefficient over the time trend and $p$ refers to lag order of the autoregressive framework. The unit root test is then implemented under the null hypothesis $\gamma=0$ against the alternative hypothesis of $\gamma<0$.

Next, the causality direction among the two main indicators was scrutinized following the standard equation:

$$
\mathrm{Y}_{\mathrm{i}, \mathrm{t}}=\alpha_{\mathrm{i}}+\Sigma \gamma^{\mathrm{k}} \mathrm{y}_{\mathrm{i}, \mathrm{t}-\mathrm{k}}+\Sigma \beta^{\mathrm{k}_{\mathrm{i}}} \mathrm{x}_{\mathrm{i}, \mathrm{t}}+e_{\mathrm{i}, \mathrm{t}}
$$

Where, $x$ and $y$ are tested stationary, $i$ stands for the country and $k$ represents the time lag. 


\subsubsection{Foreign direct investment and Economic Growth Nexus}

This empirical examination shed light on the nexus among FDI and economic advancement through the Error Correction Model and Auto Regressive Distributed Lag framework specified as follows:

$\Delta G D P G R_{\mathrm{t}}=\mathrm{a}_{0}+\sum \mathrm{p}_{\mathrm{i}=1} \mathrm{a}_{1 \mathrm{i}} \Delta G D P G R_{\mathrm{t}-\mathrm{i}}+\sum \mathrm{q}_{\mathrm{i}=1} \mathrm{a}_{2 \mathrm{i}} \Delta \mathrm{FDI}_{\mathrm{t}-1}+\sum \mathrm{q}_{\mathrm{i}=1} \mathrm{a}_{3 \mathrm{i}} \Delta$ Openness $_{\mathrm{t}-\mathrm{i}}+\sum \mathrm{q}_{\mathrm{i}=1} \mathrm{a}_{4 \mathrm{i}} \Delta$ Inflation $_{\mathrm{t}-1}+\sum \mathrm{q}_{\mathrm{i}=1}$ $\mathrm{a}_{5 \mathrm{i}} \Delta$ Credit $_{\mathrm{t}-\mathrm{i}}+\lambda \mathrm{ECT}_{\mathrm{t}-1}+\mathrm{e}_{\mathrm{t}}$

Where,

- $\quad \lambda=\left(1-\Sigma \mathrm{p}_{\mathrm{i}=1} \delta_{\mathrm{i}}\right)$, Speed of adjustment parameter with a negative sign.

- $\quad \mathrm{ECT}=\left(\triangle G D P G R_{\mathrm{t}-\mathrm{i}}-\mathbf{\theta X}_{\mathrm{t}}\right)$, the error correction term is the extracted residuals from the regression of the long-term equation.

- $\quad \boldsymbol{\theta}=\sum \mathrm{q}_{\mathrm{i}=0} \beta_{\mathrm{i}} / \alpha$, is the long run parameter.

- $\quad \mathrm{a}_{1 \mathrm{i}}, \mathrm{a}_{2 \mathrm{i}}, \mathrm{a}_{3 \mathrm{i}}, \mathrm{a}_{4 \mathrm{i} \text { and }} \mathrm{a}_{5 \mathrm{i}}$ are the short run dynamic coefficients of the model's adjustment long run equilibrium.

The aforementioned technique presented two main advantages. First, the ECM, ARDL could be applied even if variables were integrated in different orders, irrespective of whether they are I (0) or I (1) or I (0) and I (1). Second, our empirical approach enabled us to simultaneously seize both the long and short-term connection among FDI and GDP advancement in Guinea.

\section{EMPIRICAL FINDINGS}

Table 1. Summary statistics.

\begin{tabular}{l|c|c|c|c|c}
\hline Variables & Obs & Mean & Std. Dev. & Min & Max \\
\hline Growth Rate & 28 & 4.24 & 2.39 & -1.11 & 10.8 \\
\hline FDI/GDP & 28 & 2.83 & 4.45 & -0.84 & 18.8 \\
\hline Inflation & 28 & 12.4 & 8.88 & 1.93 & 34.6 \\
\hline Trade Openness & 28 & 64.9 & 18.2 & 42.4 & 113 \\
\hline Credit & 28 & 5.13 & 2.26 & 2.65 & 10.9 \\
\hline
\end{tabular}

Table 1 reports the summary statistics on Guinea for economic growth, FDI per GDP and other control variables. It should be noted that the inward FDI had already experienced a steady progress since the 1985 economic reforms. The peak level had already been attained in 2016 when China multinationals had injected huge amount of capital in bauxite mines. The year 2014 was an annus horribilis for Guinea in terms of FDI since some important investment projects were delayed or postponed due to Ebola virus outbreak.

Table 2. Pairwise correlation matrix.

\begin{tabular}{l|c|c|c|c|c}
\hline Variables & Growth Rate & FDI/GDP & Inflation & Trade Openness & Credit \\
\hline Growth Rate & 1.00 & & & & \\
\hline FDI/GDP & 0.59 & 1.00 & & & \\
\hline Inflation & -0.15 & 0.24 & 1.00 & & \\
\hline Trade Openness & 0.59 & 0.68 & 0.24 & 1.00 & \\
\hline Credit & 0.37 & 0.22 & -0.19 & 0.56 & 1.00 \\
\hline
\end{tabular}

Table 2 presents the correlation among the time series variables. The findings exhibit that GDP advancement and Credit to private sector were adversely associated with inflation. These results endorse the assertion which regards high inflation rate as a distortion factor for financial stability, and which in turn can alter the growth magnitude. On the other hand, FDI per GDP and Growth rate are positively correlated, backing the predominant theoretical literature. Fundamentally, the correlation between the series are less than $75 \%$, showing that the variables do not suffer from multi-collinearity problems. 


\subsection{Unit Root Test}

Before implementing the Bounds test procedure, we determined the series order of integration. For this motive, we adopted Augmented Dickey Fuller approach and the outcomes are reported in Table 3. From ADF and PP test results, it is evident that FDI per GDP is I (0) whereas GDP growth rate, financial advancement, Inflation and openness are I (1).

Table 3. Augmented Dickey Fuller (ADF) and Phillips Perron (PP) unit root tests.

\begin{tabular}{l|c|c|c|c}
\hline \multirow{2}{*}{ Variables } & \multicolumn{2}{|c|}{ ADF test } & \multicolumn{2}{c}{ PP test } \\
\cline { 2 - 5 } & Level & First Difference & Level & First Difference \\
\hline FDI/GDP & $-3.53^{* * * *}$ & & $-3.86^{* * * *}$ & \\
\hline GDP Growth Rate & -2.59 & $-5.92^{* * * *}$ & -2.90 & $-7.45^{* * * *}$ \\
\hline Credit & -0.69 & $-3.91^{* * * *}$ & -1.00 & $-6.06^{* * * *}$ \\
\hline Inflation & -2.20 & $-3.30^{* * * *}$ & -2.63 & $-5.65^{* * * *}$ \\
\hline Openness & 0.18 & $-3.28^{* * *}$ & 0.22 & $-5.13^{* * * *}$ \\
\hline
\end{tabular}

In our case, the Augmented Dickey Fuller (ADF) approach revealed that time series indicators had different orders of integration. In this condition, the Bounds test for co-integration appear to be the suitable mechanism. It was also essential to determine the lag selection criteria, estimating the lag length of autoregressive process for a time series is a crucial econometric exercise in most economic analyses. Table 4 presents the number of lags that were found suitable for this study.

Table 4. Lag selection criteria.

\begin{tabular}{|c|c|c|c|c|c|c|c|c|}
\hline Lag & $\mathbf{L L}$ & LR & df & $\bar{p}$ & FPE & AIC & HQIC & SBIC \\
\hline $\mathrm{O}$ & -359 & - & - & - & $3 . \mathrm{e}+06$ & 29.1 & 29.1 & 29.3 \\
\hline 1 & -300 & 118 & 25 & 0.00 & 207110 & 26.3 & 26.7 & 27.8 \\
\hline 2 & -249 & 101 & 25 & 0.00 & 34948 & 24.3 & 25.1 & $27.1 *$ \\
\hline 3 & -212 & $74.2^{*}$ & 25 & 0.00 & $31263 *$ & $23.3^{*}$ & $24.4^{*}$ & 27.2 \\
\hline \multicolumn{9}{|c|}{$\begin{array}{l}\text { Endogenous: GDP Growth rate, FDI/GDP, Inflation, Credit to private sector, Trade openness. } \\
\text { Exogenous:_Cons. }\end{array}$} \\
\hline \multicolumn{2}{|c|}{$\mathrm{E}(\operatorname{lags})[1,5]=$} & \multicolumn{2}{|c|}{ GDP Growth rate } & \multicolumn{2}{|c|}{ FDI/GDP } & Credit & Inflation & Openness \\
\hline \multicolumn{2}{|c|}{$\mathrm{rl}$} & \multicolumn{2}{|c|}{2} & \multicolumn{2}{|c|}{2} & 3 & 3 & 3 \\
\hline
\end{tabular}

The above equation displays the number of lags assigned to each of the variables. It has been incorporated in the Bounds test in order to determine the $\mathrm{F}$ and $\mathrm{t}$ statistics. This framework is adopted when the time series are integrated in different orders.

\subsection{Results of Bounds Test for Co-Integration}

The Bounds test results displayed that our F-statistic $(\mathrm{F}=5.704)$ was larger than the critical value for the upper bound I (1). This enabled us to endorse the existence of co-integration, implying a long-term association between our indicators. Therefore, we can first check the causal relationship, then conduct respectively the Error correction model and the Auto regressive distributed lag technique to capture the long and short run linkage among the variables. As a first step, Table 5 exhibits the critical values of the computed $\mathrm{F}$ and $\mathrm{t}$ statistics, enabling the authors to endorse or deny the co-integration among the series.

\subsection{Results of Granger Causality Wald test between Economic Growth and FDI/GDP}

Table 6 presents the outcomes of the Granger Wald test among per GDP FDI net inflows and GDP Growth rate. It was not possible to refute the assumption that per GDP foreign investment granger caused economic advancement in the Guinean context. Moreover, irrespective to the number of lags used in the analysis, the 
causality among the two variables remained bi-directional, suggesting the existence of causal linkage among foreign capital and GDP advancement in Guinea.

Table 5. ARDL bounds test.

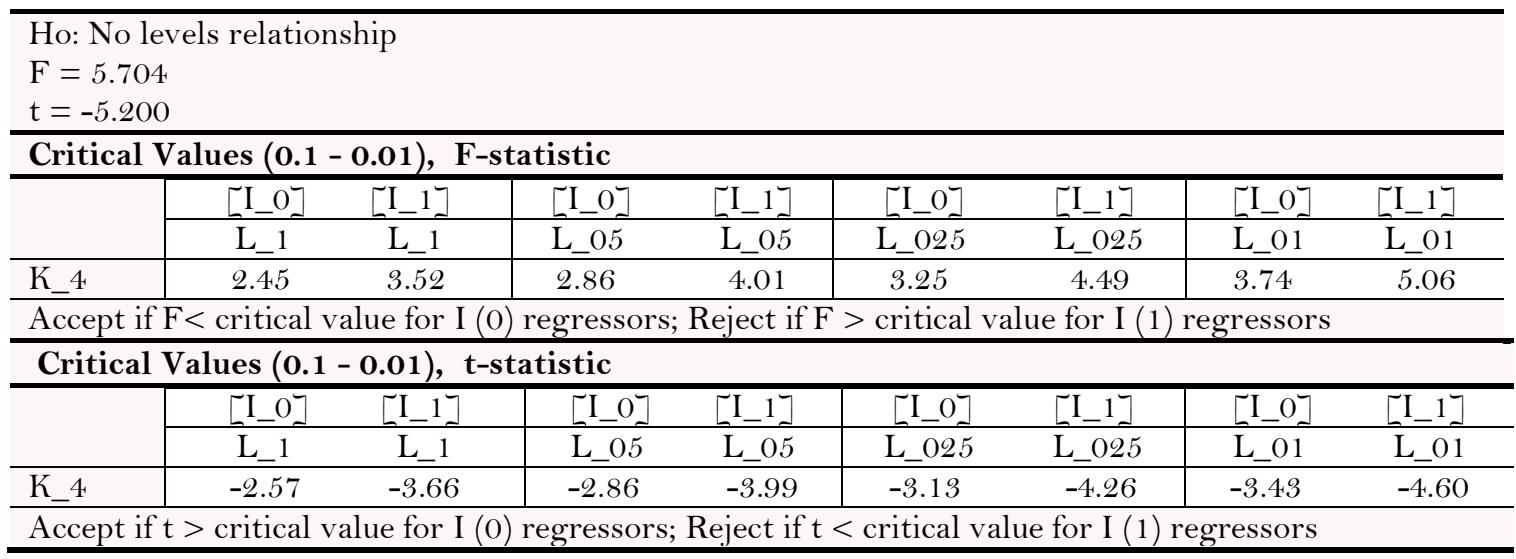

Table 6. Causality among growth rate and FDI per GDP inflows.

\begin{tabular}{l|c|c|c|c|c}
\hline Equation & Excluded & F & df & df_r & Prob > F \\
\hline Growth Rate & FDI & 6.34 & 5 & 12 & 0.0042 \\
Growth Rate & ALL & 6.34 & 5 & 12 & 0.0042 \\
\hline FDI & Growth Rate & 8.32 & 5 & 12 & 0.0013 \\
FDI & ALL & 8.32 & 5 & 12 & 0.0013 \\
\hline Growth Rate & FDI & 3.98 & 6 & 9 & 0.0316 \\
Growth Rate & ALL & 3.98 & 6 & 9 & 0.0316 \\
\hline FDI & Growth Rate & 4.60 & 6 & 9 & 0.0206 \\
FDI & ALL & 4.60 & 6 & 9 & 0.0206 \\
\hline
\end{tabular}

\subsection{Results of Error Correction Model}

The main findings from the Error Correction framework are reported in Table 7. Intrinsically, the growth rate in $\mathrm{L}_{1}(-3.53)$ is the speed of adjustment or error correction term towards equilibrium, shown as negative and significant at $1 \%$. It endorses a long-term association among FDI per GDP net inflows, GDP growth rate, credit to private sector, inflation and trade openness. Basically, in the long term, regressions display foreign direct investment to have positive impact on economic advancement in Guinea at 1\% magnitude. This outcome suggests that $1 \%$ raise in FDI per GDP leads to 0.45 increase in GDP growth.

Table 7. The error correction model (Long run dynamics).

\begin{tabular}{|c|c|c|c|c|c|c|}
\hline Credit/PS & Coef. & Std. Err. & $\mathbf{t}$ & $\mathbf{P}>[\mathbf{t}]$ & \multicolumn{2}{|c|}{ [95\% Conf. Interval] } \\
\hline \multicolumn{7}{|l|}{ ADJ } \\
\hline Growth Rate L1. & -3.53 & 0.68 & -5.20 & 0.001 & -5.14 & -1.92 \\
\hline \multicolumn{7}{|l|}{ LR } \\
\hline FDI/GDP & 0.45 & 0.08 & 5.56 & 0.001 & 0.25 & 0.64 \\
\hline Credit & 0.67 & 0.12 & 5.19 & 0.001 & 0.36 & 0.97 \\
\hline Inflation & -0.02 & 0.02 & -1.02 & 0.343 & -0.09 & 0.03 \\
\hline Openness & -0.09 & 0.02 & -3.22 & 0.015 & -0.18 & -0.02 \\
\hline
\end{tabular}

This finding is in line with the predominant literature related to foreign investment in Africa and other developing regions. Those views posit that FDI may have significant impact on recipient country via direct or spillover effect. FDI can also stimulate GDP advancement through the raise of total factor productivity and the efficient utilization of resources within the host nation. This objective might be achievable through the following mechanisms: linkages among FDI and domestic businesses, and other FDI generated externalities for the local 
economic structure. Through the deployment of advanced technologies, introduction of new management practices and the training of human capital, foreign direct investment may also increase productivity in the recipient country.

Moreover, credit to private sector positively influence GDP growth rate at $1 \%$ significance level, suggesting that every percent increase in financial intermediation causes 0.67 raise in economic growth. This finding totally endorses the theoretical assumption which asserts that better financial intermediation expands available funds in the local economy, reduces the cost of capital and provides adequate services that are necessary to finance both domestic and foreign investors. The coefficient for inflation is negative and insignificant whereas openness variable negatively influence growth at $5 \%$ significance level

\subsection{Results of Auto Regressive Distributed Lag Model (ARDL)}

We found evidence in favor of short-run dynamics as shown by the signs and values of the coefficients for the variables, FDI, GDP growth, Credit to private sector, inflation and trade openness with their corresponding significant t-statistic. Table 8 presents these short run coefficients suggesting the same story revealed by the long run analysis.

Table 8. The ARDL model (Short run dynamics)

\begin{tabular}{|c|c|c|c|c|c|c|}
\hline Growth Rate & Coef & Std. Err. & $\mathbf{t}$ & $\mathbf{P}>[\mathrm{t}]$ & \multicolumn{2}{|c|}{$[95 \%$ Conf. Interval } \\
\hline L1. & -1.16 & 0.37 & -3.14 & 0.016 & -2.04 & -0.28 \\
\hline \multicolumn{7}{|l|}{ FDI/GDP } \\
\hline-- & 0.48 & 0.14 & 3.26 & 0.014 & 0.13 & 0.83 \\
\hline L2. & 0.37 & 0.19 & 1.91 & 1.91 & -0.08 & 0.83 \\
\hline \multicolumn{7}{|l|}{ Credit } \\
\hline-- & 0.53 & 0.54 & 0.99 & 0.35 & -0.74 & 1.81 \\
\hline L1. & 0.79 & 0.63 & 1.25 & 0.25 & -0.70 & 2.29 \\
\hline \multicolumn{7}{|l|}{ Inflation } \\
\hline-- & -0.23 & 0.06 & -3.59 & 0.009 & -0.38 & -0.07 \\
\hline $\mathrm{L} 1$. & -0.12 & 0.08 & -1.51 & 0.17 & -0.31 & 0.06 \\
\hline L2. & 0.18 & 0.07 & 2.34 & 0.05 & -0.001 & 0.36 \\
\hline L3. & 0.07 & 0.09 & 0.77 & 0.46 & -0.14 & 0.29 \\
\hline \multicolumn{7}{|l|}{ Openness } \\
\hline-- & -0.11 & 0.07 & -1.57 & 0.16 & -0.29 & 0.05 \\
\hline L1. & -0.006 & 0.08 & -0.08 & 0.94 & -0.20 & 0.19 \\
\hline L2. & -0.10 & 0.08 & -1.22 & 0.26 & -0.29 & 0.09 \\
\hline L3. & -0.10 & 0.08 & -1.14 & 0.29 & -0.31 & 0.10 \\
\hline _Cons & 19.4 & 5.02 & 3.88 & 0.006 & 7.58 & 31.3 \\
\hline
\end{tabular}

This suggests that FDI per GDP [L1], [L2] positively and significantly influences economic growth in the Guinean context. It means that 1 percent raise in FDI discretely leads to 0.74 and 0.37 increase in GDP growth. This outcome fundamentally agrees with the classical FDI theories which presume foreign investment to have strong impact (direct and indirect) on GDP growth. With financial development indicator, the coefficients remain positive, meaning that credit to private sector remains a key factor that counts for economic growth in Guinea.

The regression coefficient [L1] turns negative and insignificant when inflation interacts with economic growth indicator. Trade openness [L1], [L2] and [L3] are negatively and insignificantly connected with GDP growth in the Guinean context. 


\subsection{Robustness Check}

The aforementioned findings need to undergo further diagnostic tests in order to assess the model stability, normality and make sure that our variables are not serially auto-correlated and heteroskedastic.

Durbin-Watson d-statistic test: $(18,25)=1.831624$.

This outcome from Durbin-Watson test (1.831624) obviously advocate that our variables are not serially correlated, showing the reliability of the findings.

Table 9 presents findings of the Breusch-Godfrey LM test. It is a commonly used framework when examining the autocorrelation bias among time series variables.

Table 9. Breusch-Godfrey LM test.

\begin{tabular}{l|c|c|c}
\hline Lags (p) & Chi2 & df & Prob > chi2 \\
\hline 3 & 0.97 & 3 & 0.80 \\
\hline Note: Ho: no serial correlation.
\end{tabular}

The Breusch-Godfrey calculated value endorses the preceding finding from Durbin-Watson test. Prob $>$ chi $2=$ (0.8071) is larger than $5 \%$, refuting serial autocorrelation issue among the indicators.

White's test for Ho: Homoskedasticity against Ha: unrestricted heteroskedasticity

chi2 $(24)=25.00$

Prob $>$ chi $2=0.4058$

The computed value from the White's test, Prob $>$ chi $2=(0.4058)$ is larger than $5 \%$, negating the presence of heteroskedasticity problem. Thus, our empirical design was proved to be appropriate for such kind of analysis.

Table 10 refers to Cameron \& Trivedi's decomposition of IM-test. It is a diagnosis test showing that the time series are or not normally distributed.

Table 10. Cameron \& Trivedi's decomposition of IM-test.

\begin{tabular}{l|c|c|c}
\hline Source & Chi2 & df & p \\
\hline Heteroskedasticity & 25 & 24 & 0.40 \\
\hline Skewness & 12.1 & 17 & 0.79 \\
\hline Kurtosis & 1.41 & 1 & 0.23 \\
\hline Total & 38.5 & 42 & 0.62 \\
\hline
\end{tabular}

The results from Cameron and Trivedi's decomposition test [Prob > Chi2 superior than 5\%] provide evidence that residuals are normally distributed.

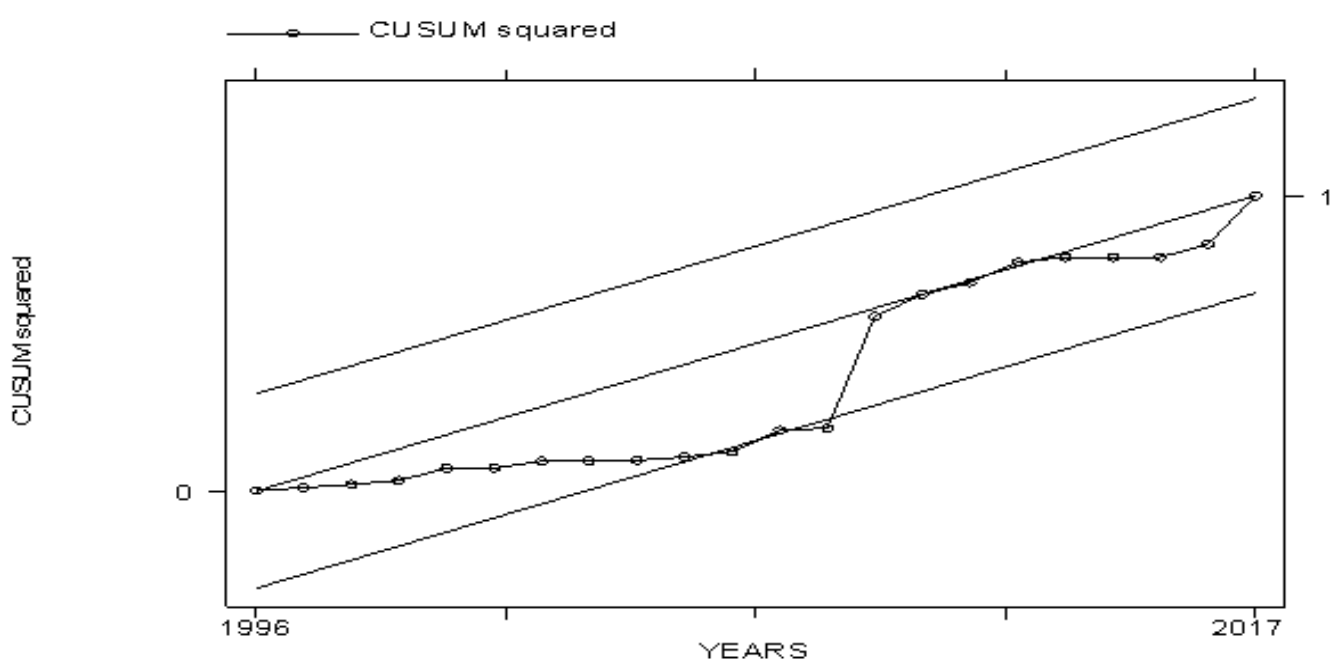

Figure 3. CUSUM squared test. 
Figure 3 presents the CUSUM squared test which is the last diagnosis test exhibiting the stability of our empirical framework. This CUSUM graph clearly endorses the stability of the model. Thus, it showed that the study had adopted an appropriate method.

\section{CONCLUSION}

Public policies towards foreign direct investment as well as its features have considerably varied over time. Since the independence in October 1958 until 1984, inward FDI inflows were greatly concentrated in the extraction of natural resources. Besides these major contracts, some state-to-state deals generated micro industries that aimed to transform local Guinean agriculture products. Those agreements were concluded with Soviet Union, China, and Cuba, and were driven politically and ideologically rather than with the economic motives. In 1985, Guinea shifted from a planned and centralized to liberal market friendly economy. Thus, Government lifted restrictions and offered inducements in order to entice foreign investors.

Foreign investment induced impact on economic advancement has not previously been analyzed in the Guinean context. To fill this research gap, this study could emerge as a pioneering work, which tested the causality direction and investigated the short- and long-term influence of FDI on GDP growth over the period 1990-2017. Per GDP FDI and GDP growth rate were respectively adopted as FDI estimates and economic advancement indicators. The long-term findings from Error correction model displayed foreign direct investment having positive impact on economic advancement in Guinea at $1 \%$ magnitude. This outcome suggests that $1 \%$ raise in FDI per GDP leads to 0.45 increase in GDP growth. This finding is in line with the predominant literature related to foreign investment in Africa and other developing regions. Those views posit that FDI may have significant impact on recipient country via spillover effect. FDI can also stimulate GDP advancement through the raise of total factor productivity and the efficient utilization of resources within the host nation.

Likewise, the short run coefficients suggest the same story exposed by the long run investigation. FDI per GDP [L1], [L2] positively and significantly influences economic growth in the Guinean context. They recommend that 1 percent raise in FDI discretely leads to 0.74 and 0.37 increase in GDP growth. Additionally, with financial development indicator, the coefficients remain positive, suggesting that credit to private sector stays a key factor that counts for economic growth in Guinea. The regression coefficient [L1] turns negative and insignificant when inflation interacts with economic growth indicator. Trade openness [L1], [L2] and [L3] are negatively and insignificantly connected with GDP growth in the Guinean context.

Even though these empirical findings endorse foreign direct investment positively affect GDP advancement in Guinea, it is obvious that not all types of foreign investment seem to be advantageous for the recipient country. During the last decade, Guinean GDP growth was mainly driven by the export of raw materials which has a very limited impact on the local economy. For this reason, government should have different attitudes towards diverse forms of FDI. Resource seeking investment were discouraged for the benefit of market or efficiency seeking type. Substantial incentives must be given to investors who are willing to transform natural resources locally. At the same time, authorities should heavily invest in human capital, infrastructure and reinforce political institutions so that Guinea can be a favorable destination for foreign investment.

Funding: This study received no specific financial support.

Competing Interests: The authors declare that they have no competing interests.

Authors' Contributions: All authors contributed equally to the conception and design of the study.

\section{REFERENCES}

Abdillahi, M. N., \& Mohd, S. (2021). Impact of foreign direct investment on economic growth in Ethiopia: Empirical evidence.

Latin American Journal of Trade Policy, 4(10), 56-77.Available at: https://doi.org/10.5354/0719-9368.202 1.61853. 
Carlos, E. F., \& Eddie, V. Z. (2015). Foreign direct investment and gross domestic product growth. Procedia Economics and Finance, 24, 198-207.Available at: https://doi.org/10.1016/S2212-5671(15)00647-4.

Gaurav, A. (2015). Foreign direct investment and economic growth in BRICS economies: A panel data analysis. Journal of Economics, Business and Management, 3(4), 42 1-424.Available at: https://doi.org/10.7763/JOEBM.2015.V3.221.

Irfan, U., Mahmood, S., \& Farid, U. K. (2014). Domestic investment, foreign direct investment and economic growth nexus: A case of Pakistan. Economics Research International, 2014.Available at: https://dx.doi.org/10.1155/2014/592719.

Liming, H. (2014). Does and how does foreign direct investment promote the economic growth? Evidence from dynamic panel data of Prefecture city in China nations. IERI Procedia, 6, 57-62.Available at: https://doi.org/10.1016/j.ieri.2014.03.010.

Masipa, T. (2014). The impact of foreign direct investment on economic growth and employment in South Africa: A time series analysis. Mediterranean Journal of Social Sciences, 5(25), 18.Available at: https://doi.org/10.5901/mjss.2014.v5n25p18.

Mohammad, M. A., Mahmoud, K. A., \& Liu, Y. (2014). Economic growth and foreign direct investment inflows: The case of Qatar. Procedia-Social and Behavioral Sciences, 109, 1040-1045.Available at: https://doi.org/10.1016/j.sbspro.2013.12.586.

Nicholas, O. M. (2021). Foreign direct investment and economic growth in Kenya: An empirical investigation. International Journal of Public Administration, 1-12.Available at: https://doi.org/10.1080/01900692.202 1.1872622.

Olawumi, A. D., \& Olufemi, P. A. (2016). Impact of foreign direct investment on economic growth in Africa. Problems and Perspectives in Management, 14(2-2), 289-297.Available at: https://dx.doi.org/10.21511/ppm.14(2-2).2016.04.

Oscar, C., \& Edson, K. (2016). Foreign direct investment and economic growth in Botswana: A dynamic causality test. British Journal of Economics, Management \& Trade, 11(3), 1-8.Available at: https://doi.org/10.9734/BJEMT/2016/21723.

Paula, N. (2014). Foreign direct investment and economic growth, the case of Romania. Procedia Economics and Finance, 15, 577582.Available at: https://doi.org/10.1016/S2212-5671(14)00514-0.

Sabina, S., \& Eldin, M. (2015). Knowledge spillovers, absorptive capacities ans the impact of foreign direct investment on economic growth: Empirical evidence from transition economies. Procedia-Social and Behavioral Sciences, 195, 614623.Available at: https://doi.org/10.1016/j.sbspro.2015.06.142.

Sajid, A., \& Lan, P. N. (2010). Foreign direct investment and economic growth in Vietnam. Asia Pacific Business Review, 16(1-2), 183-202.Available at: https://doi.org/10.1080/10438590802511031.

Xiaoying, L., \& Xiaming, L. (2005). Foreign direct investment and economic growth: An increasingly endogenous relationship. World Development, 33(3), 393-407.Available at: https://doi.org/10.1016/j.worlddev.2004.1 1.001.

Zuzana, S. (2014). A causal relationship between foreign direct investment, economic growth and export for Slovakia. Procedia Economics and Finance, 15, 123-128.Available at: https://doi.org/10.1016/S22 12-5671(14)00458-4. 